\title{
FINANCING SCHEMES FOR RESIDENTIAL, GRID-CONNECTED PV SOLAR SYSTEMS IN BCS, MEXICO
}

\author{
A. BERMUDEZ-CONTRERAS ${ }^{1} \&$ A. IVANOVA-BONCHEVA ${ }^{2}$ \\ ${ }^{1}$ Department of Fisheries Engineering, Universidad Autonoma de Baja California Sur, Mexico. \\ ${ }^{2}$ Department of Economics, Universidad Autonoma de Baja California Sur, Mexico.
}

\begin{abstract}
This article presents two proposals to spur the extensive adoption of grid-connected, residential, solar photovoltaic systems in the Mexican state of Baja California Sur. To this aim, electricity generation costs and subsidies were estimated first, together with time-of-generation avoided costs that could result from the implementation of such solar systems. An overview of financing mechanisms for solar and other renewable energies around the world is also presented followed by current mechanisms available in Mexico. The first proposal is centered around the operation of a solar energy service company that would receive the avoided cost of generation as compensation in return for sourcing, installing, and maintaining solar PV systems on residential users' roofs. This would free up the residential user from any future electricity payments. The second proposal consists in the implementation of a feed-in tariff (FiT), currently unavailable in Mexico for residential users. The FiT could be funded from the avoided generation cost in conventional plants plus the corresponding savings from self-generation of electricity. Alternatively, the option of funding the FiT from small increases in electricity prices to all customers was also explored. Present value analyses suggest that both proposals are worthwhile pursuing in Baja California Sur.

Keywords: Baja California Sur, feed-in tariff, financing, grid-connected, Mexico, photovoltaics, solar.
\end{abstract}

\section{INTRODUCTION}

Baja California Sur (BCS) is a state located in northwest Mexico. It has the lowest population density in the country (9 inhabitants $/ \mathrm{km}^{2}$ ) and, as of 2010, it was also the least populated state, albeit with a population growth rate well above the national average. In particular, between years 2000 and 2010 the country's population grew at an annual average rate of $1.4 \%$ while BCS's population grew at $4 \%$ annually on average [1].

This has inevitably had impacts on the demand for services, including electricity. Thus, BCS had the highest growth rates in electricity consumption (Fig 1) and in maximum electricity demand in Mexico in recent years (2001-2010: 6.1\% annual average). Since population (and the local economy) is expected to continue to grow at a fast pace in the future, electricity is also in demand. Expectations of maximum electricity demand growth rate for the current decade (2011-2020) in BCS equal 6.4\% and 7\% up to 2026 [2]. Since BCS operates in isolation from the national electricity grid, there is an urgency to continuously build new power plants locally so as to keep up with the rising demand. Given the electricity generation technologies currently in place and those under construction or in planning [2,3], the emissions of greenhouse gases (GHG) associated with electricity generation in BCS are also expected to increase in the coming years. Renewable energy technologies, such as solar photovoltaics (PV), have the potential to reduce the high emissions levels resulting from electricity generation in BCS.

\section{ELECTRICITY GENERATION TECHNOLOGIES}

Most energy needs around the world are fulfilled by burning fossil fuel [4, 5]. One of the most important consequences of this is the release of GHG emissions (GHGE). By the end of 


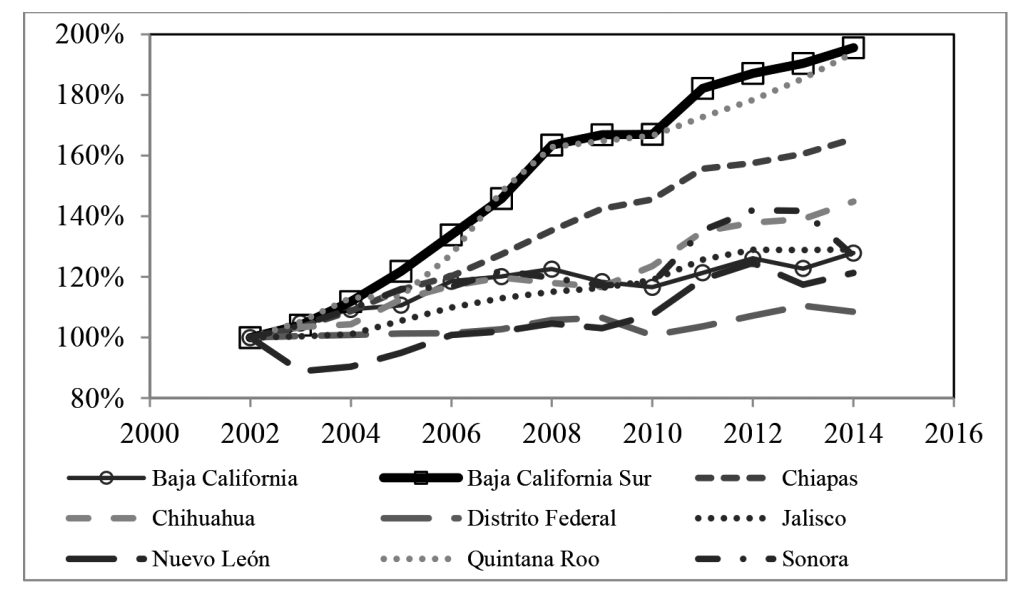

Figure 1: Normalized electricity consumption in selected states in Mexico 2002-2014. Reference (normalization) value: consumption in year 2002 for each state.

2010, the global concentration of $\mathrm{CO}_{2}$ emissions in the atmosphere had already passed the 390 ppm mark [6].

This situation also prevails in BCS. Here, road transport is driven by petrol and diesel, while LPG is used as a heat source for cooking. Similarly, electricity in BCS is generated mostly in the Federal Electricity Commission's (CFE, the state-owned, national power utility and sole electricity provider in Mexico) power plants mostly by burning diesel oil and a type of heavy residual fuel similar to heavy fuel oil no. 6 (see the generation technology breakdown presented in Fig 2). Consequently, power generation in BCS is undoubtedly contributing to the rising GHGE observed worldwide. The GHGE factor for the state has been placed at $0.892 \mathrm{~kg} \mathrm{CO} 2 \mathrm{e} / \mathrm{kWh}$ in a recent study [7].

Fortunately, BCS has clean, renewable energy (RE) resources that can be used to generate electricity $[8,9]$. The use of RE to mitigate GHGE has been extensively studied around the world [10-17]. Furthermore, in addition to RE's GHGE mitigation potential, RE can also have wider impacts on national development including social, political, and economic growth, enhancement of energy security, and job creation $[6,18]$.

In BCS, one of the most abundant renewable energy sources is solar energy. Solar radiation levels throughout BCS are amongst the highest in Mexico, reaching levels above $7 \mathrm{kWh} / \mathrm{m}^{2} / \mathrm{d}$ in summer with yearly averages in the range of $5.6-6.5 \mathrm{kWh} / \mathrm{m}^{2} / \mathrm{d}$. To gain some perspective, daily solar radiation in Germany averages between 2.5 and $3.3 \mathrm{kWh} / \mathrm{m}^{2}$ [19]. Despite this being significantly lower than in BCS (about 50\%), Germany is a world leader in the installation of solar PV systems. This potential has been advantageously exploited for more than two decades in rural settlements to generate off-grid electricity. More recently, gridconnected, residential solar PV systems (GCRPVS) have also appeared in the local market. However, the high upfront capital cost involved in the installation of GCRPVS has been an obstacle to their wide spread use amongst residential customers in Mexico and certainly in BCS. The following sections will review the local generation costs and electricity subsidies alongside financing options with the aim of sketching out a proposal to facilitate the wide spread use of GCRPVS in BCS. 


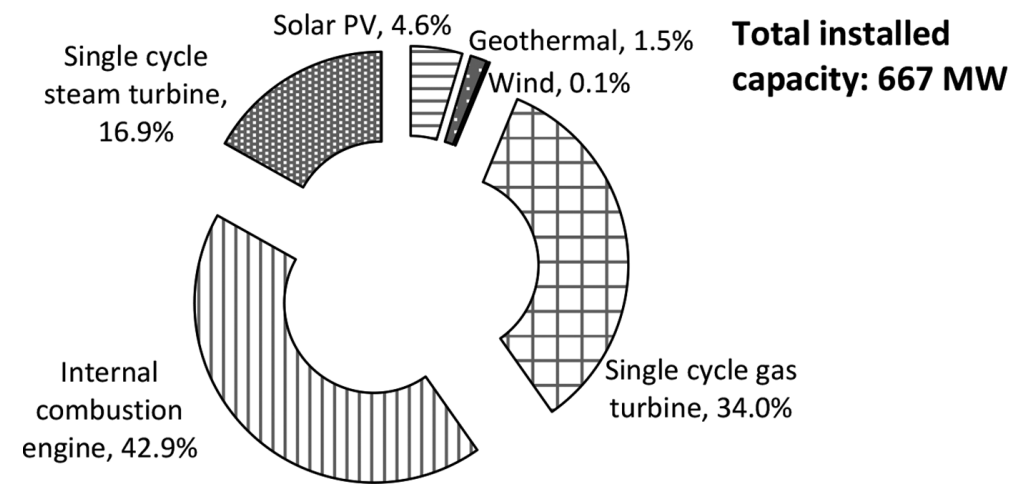

Figure 2: Power generation technologies breakdown in BCS. Internal combustion engines and steam turbines use heavy fuel oil and gas turbines use diesel.

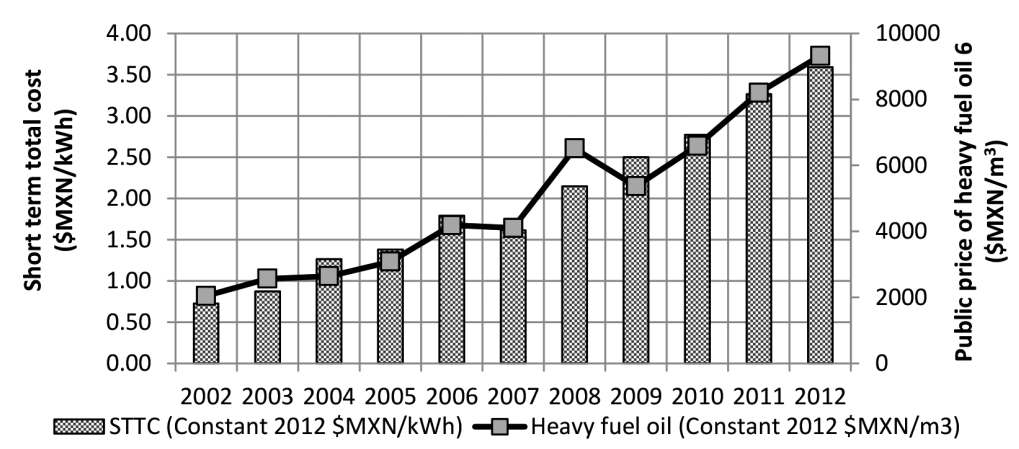

Figure 3: Short-term total cost (marginal generation cost) and fuel price. Reference exchange rate: $1 \mathrm{USD}=13 \mathrm{MXN} \$$.

\section{ELECTRICITY GENERATION COST}

In addition to the environmental effects of the prevailing generation technologies, the cost of local generation has been rising steadily during the past decade and is nowadays amongst the highest in the country. A significant part of this cost comes from fuel and fuel shipping costs, as they arrive only by sea due to the state's geographic isolation. Fig 3 shows the evolution of the so-called 'Short Term Total Cost' (STTC, the marginal generation cost) in BCS between 2002 and 2012. STTCs are reported monthly by the CFE for every hour of every month [20].

\section{RESIDENTIAL ELECTRICITY SUBSIDIES AND AVOIDED COSTS}

Electricity subsidies are common practice worldwide. Despite the market distortions they introduce, they play an important role in boosting domestic industries competitiveness as well as in social welfare and stability. This is the case of residential electricity consumers in Mexico and BCS, who are the recipients of significant subsidies funded from taxpayers money directly in their electricity bill.

Residential electricity subsidies in BCS were estimated using monthly electricity consumption and billing information provided by CFE's local office together with monthly averages of the STTC so as to calculate the difference between the generation cost and the 


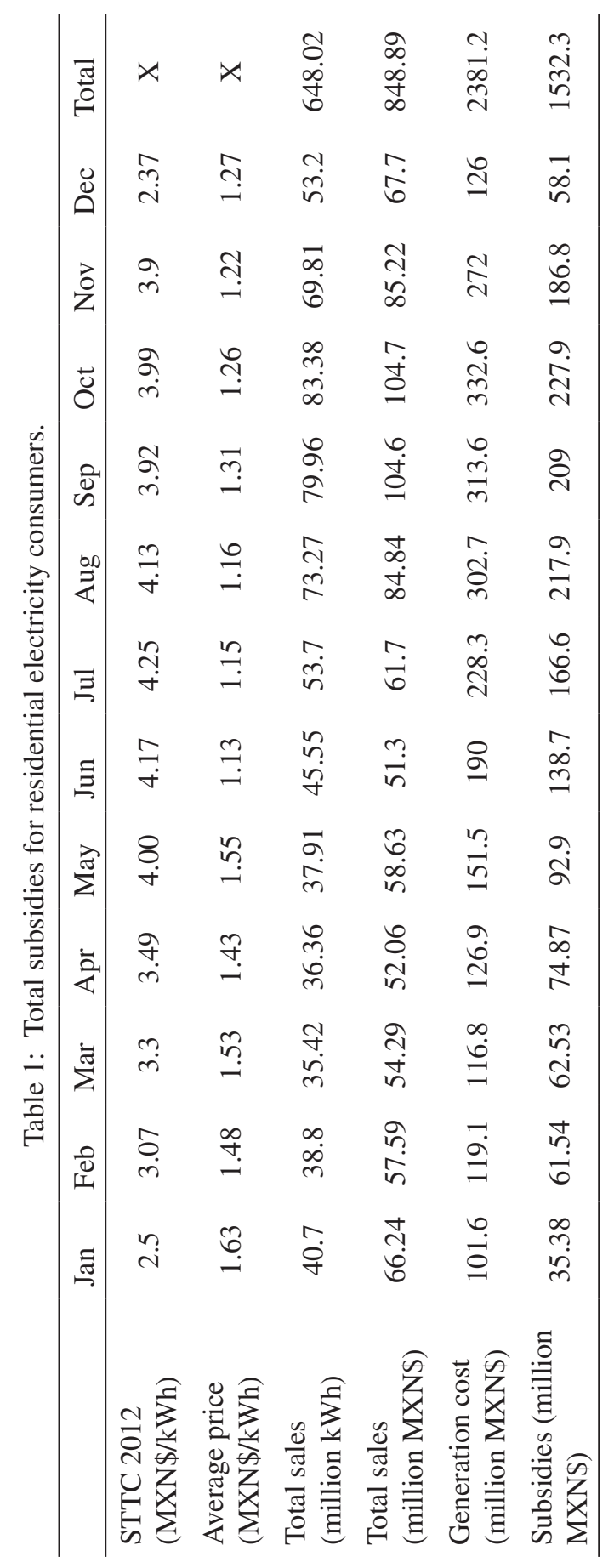


recouped expenses through customers' payments. The results are presented in Table 1. For 2012, the total amount of subsidies for residential customers equals \$1 532 million Mexican pesos. On average, this equates to $\$ M X N 2.36 / \mathrm{kWh}$ (For reference 1 \$USD = $13 \$ \mathrm{MXN}$ ).

Besides subsidies, an important quantity is the avoided cost for CFE. While the STTC represents the marginal generation cost for every hour, generation is not uniform and varies with demand. Similarly, a GCRPVS only generates electricity during daylight hours and its generation is also variable. Therefore, in order to estimate the avoided generation costs for the CFE resulting from the use of GCRPVS, a weighted average considering the hourly generation curve of a GCRPVS and the hourly STTC is required. The former was obtained using specialist solar simulation software PVsyst, and the hourly STTC data were obtained from CFE's publications [20]. With these considerations, the average avoided generation cost in BCS during 2012 was estimated at $\$ M X N 3.8259 / \mathrm{kWh}$.

\section{NATIONAL POLICY IN ELECTRICITY GENERATION}

In the provision of electricity for public use, there are several instruments that shape the national planning and regulatory framework. In a thorough review of 15 of such energy policy documents, four main objectives related to this work were identified: to generate electricity at the lowest cost, to generate more electricity from renewable sources, to reduce greenhouse gas emissions, and to diversify the energy sources that make the generation mix. Distributed electricity generation by means of GCRPVS would undoubtedly contribute to achieve all of these objectives simultaneously. However, as mentioned above, financing of GCRPVS is a significant hurdle that must be overcome to promote their wide spread adoption in BCS and elsewhere in Mexico.

\section{INCENTIVES AND FINANCING MECHANISMS}

The following sections summarize renewable and solar PV financing and promotion mechanisms used around the world. Numerous combinations and hybrids of these approaches are in place in different countries. Thus, the schemes presented include the main ones in use at present. For more detail, the International Energy Agency (IEA) and the International Renewable Energy Agency (IRENA) have put together a database of renewable energy support mechanisms by country and their development in time [21]. Similarly, REN21 in its Global Status Report [22] presents a good summary of policies and instruments to promote and support renewable energy currently in place by country around the world. While the implementation approaches and types are diverse, it is possible to identify some main categories, which are described below [23-25].

\subsection{Quantity-based incentives}

Under these mechanisms, a given sector (consumers, producers, or suppliers) has an obligation to source a certain percentage or amount of its electricity from renewable sources. The electricity can either be self-generated or purchased from 'green' generators. To add some flexibility to the system, many countries choose to allow the obliged party to reach its renewable quota by means of tradable green certificates. In this manner, green generators can sell their electricity in the wholesale market like any other generator and also have the possibility of trading their certificates in a green certificates market in those countries where this is in place. 


\subsection{Tenders or auctions}

These are also instruments based on quantity where the regulator has a renewable energy project of specified capacity and takes bids from participants interested in developing the project (similar to an auction). Usually, these mechanisms are based on the provision of electricity for a certain number of years at a particular unit cost and the participant with the lowest financing requirements wins the tender and the exclusive benefit of the support granted.

\subsection{Net metering}

This mechanism is used mainly in the promotion of decentralized solar electricity generation (i.e. distributed generation) in grid-connected systems. This scheme considers the net difference between the electricity that a user (or producer, in this case) exports to the grid and the electricity that he takes from the grid. In most countries, if the user exports more electricity to the grid than what he took, the grid operator or electricity service provider is obliged to take the surplus and pay the user for it. The amount received by the user varies from country to country but as a general rule, the minimum amount received would be the current tariff since every $\mathrm{kWh}$ generated by the user represents $1 \mathrm{kWh}$ that the user will not pay for to the service provider.

\subsection{Feed-in tariffs}

A FiT fixes a unit price per $\mathrm{kWh}$ for the purchase of renewable electricity that reflects the real cost of generations for every technology (solar PV, in this case) plus a reasonable rate of return. FiTs are normally guaranteed for long times (15-20 years) in order to provide security for the investment. FiTs require the electricity provider or grid operator to buy all renewable electricity generated regardless of the actual demand. Usually, FiTs are financed by very small increases in electricity retail prices for all consumers with considerations as to the way to distribute the additional burden fairly amongst consumers. FiTs have proven to be the most effective mechanism to grow the solar PV market around the world.

\subsection{Tax and investment incentives}

These mechanisms are frequently used as complements to the mechanisms described above during early stages of renewable energy markets. They include investment incentives such as grants (subsidies), tax credits and incentives, and soft loans. They are usually based on the capacity of the systems that will be installed and are focused on investment.

\section{SOLAR ENERGY INCENTIVES AND FINANCING IN MEXICO}

At present, solar power in Mexico amounts to less than $1 \%$ of Mexico's total energy production, meaning utility-scale solar power is not only in its infancy, it is a huge opportunity.

Nevertheless, entry into the Mexican solar industry market has specific hurdles. Mexican utilities are state-owned (LSPEE, 1975), making it difficult for independent power providers (IPPs) to enter the market, which includes power generation, transmission, and distribution controlled by the government's CFE. This means any development of the solar industry requires government backing. But, the last few years has seen some progress: IPPs are now permitted to sell power to CFE, and corporations can produce electricity for their own use 
with the possibility of selling any surplus to the state-owned national grid (also owned and operated by CFE). Finally, so-called small producers (up to $30 \mathrm{MW}$ ) can also generate power but must sell all of it to CFE (unless power is produced for self-consumption in small, isolated, rural communities) [26-28]. Nevertheless, the lucrative residential solar power market remains totally under state control.

The utility-scale solar energy is still underdeveloped in Mexico. Until recently, Mexico's solar industry has focused on small, off-grid photovoltaic installations in remote areas to supply over $3 \%$ of rural population not currently connected to the grid [29]. Today, 80,000 rural PV systems are in operation across the country. But even with relatively high electricity prices (about $\$ 0.10$ per kilowatt hour higher than the US), large-scale solar power plant projects have not been forthcoming, in part due to the state-controlled energy sector monopoly and high domestic reserves of oil and gas.

The lack of credit and financial incentives for renewable energy projects had also slowed solar development until the Renewable Energies and Energy Transition Financing Law passed [30]. This Law calls for a framework to finance and regulate renewable energy development by consolidating existing financial and contractual incentives through SENER [30], Mexico's national energy ministry. Available incentives and financing sources in Mexico are detailed below in the following section.

\subsection{Incentives}

\subsubsection{Net metering}

Since 2007, the Mexican government issued regulations and a methodology for net metering. The scheme is mandated by an interconnection contract signed between CFE and the interested user or the company. These contracts have an indefinite duration and are available for residential users with GCRPVS up to $10 \mathrm{kWp}$ in size. Other users connected to the grid in low voltage $(>1 \mathrm{kV})$ can install up to $30 \mathrm{kWp}$. Users need to cover the cost of a bi-directional meter and can credit the cost of their old meter (approximately USD 140). Users can credit $100 \%$ of the power generated from their total power consumption. If production exceeds consumption, the user has up to 12 months to credit the difference, after which time the credit is lost.

\subsubsection{Immediate depreciation}

Article 40 of the Income Tax Law indicates that companies and organizations can opt for immediate depreciation of $100 \%$ of the investments made in machinery and equipment for electricity generation from renewable energy sources. For immediate depreciation, the equipment must last at least 5 years. Otherwise, the company will have to cover the taxes corresponding to a normal depreciation process (10 years). Only companies or individuals with entrepreneurial activity tax schemes can apply for this tax incentive.

\subsubsection{Financing at preferential rates}

In 2010, the National Trusteeship for Electric Energy Saving (FIDE) issued a program to finance renewable power generation projects of up to $500 \mathrm{~kW}$. This financial support has the following characteristics:

- Up to $100 \%$ of the total project cost.

- Interest rates below commercial rates (2-5 points below, commercial rates average $12 \%$ ).

- Interest charged on remaining balance and not full loan amount. 
- Up to 20 quarterly fixed payments (5 years).

- Applicable for companies and organizations incorporated in Mexico and residential project owners [29].

\subsubsection{Preferential transmission tariffs}

In the particular case of the remote self-supply generation model, reduced transmission tariffs apply to power generated through renewable sources:

- Regular transmission tariff charged by CFE to the electric energy generated through traditional sources: MXN\$ 0.30 to MXN\$ 0.40/kWh (USD 0.022 to USD 0.030) depending on the location.

- Transmission tariff for remote self-supply generation based on renewable energies: \$MXN 0.14/kWh (USD0.009).

In addition to any applicable incentives, the largest incentive for solar power project development in Mexico is the high-power tariffs charged by CFE.

\subsection{Financing sources in Mexico}

The most important financing programs supporting private solar projects in Mexico include the following.

\subsubsection{Trusteeship for Electric Energy Saving (FIDE)}

The Trusteeship for Electric Energy Saving (Fideicomiso para el Ahorro de Energía) was established in 1990 to support governments' energy savings programs. Providing financial solutions through Nacional Financiera (national development bank) develops diverse projects for energy savings. CFE and its clients are the beneficiaries of this trusteeship [29].

Any CFE client, being an individual or a company, can request for FIDE's financing services. The solicitant can receive up to MXN\$250,000 (USD 18,700) to finance the installation of solar water heaters, photovoltaic solar panels or specific technologies required based on the energy savings as a result of its installation.

The installer must provide the estimate return on investment calculation and total project cost and based on this, FIDE will establish the time to pay the loan, whose interest rate is calculated as follows:

- [TIIE 'Equilibrium Inter-banks Interest Rate' + 6\%] + IVA (value added tax).

- Based on the rates in force on August 15, 2013, this calculation would be: $[4.32 \%+6 \%]+16 \% \operatorname{tax}=11.97 \%$.

It is important to note that the maximum of MXN\$250,000 corresponds to those loans authorized without any mortgage guarantee. If the project requires higher investment, then FIDE will request a mortgage guarantee for the exceeding amount.

\subsubsection{National Infrastructure Fund (FONADIN)}

FONADIN (National Infrastructure Fund), dependent on the Banco Nacional de Obras y Servicios (BANOBRAS), supports investments in infrastructure projects promoted by the federal, local and municipal governments, mainly in areas of communications, transportation, hydraulics, environment, and tourism, and developed by private sector par- 
ties that are awarded concessions, permits, or contracts, constituting public-private partnerships [29].

Financial support provided by FONADIN can be given under two models:

- Recoverable support: Financing for preliminary studies, assessments, guarantees (credit, stocks', development, and risk) and capital investment.

- Non-recoverable support: Subventions to provide financial stability to non-profitable public projects with high social impact, as well as grant funds for preliminary studies for public projects or 'high social interest' projects with private participation and that have their own investment source.

Since FONADIN is authorized to financially support simple loans to complex venture capital investments and structured financial instruments, financing solutions offered are highly customized to each project or case.

\subsubsection{Private banks}

CI Banco is a private Mexican bank that has developed an area specialized in green projects at preferential interest rates. The most successful loan model offered by this bank is 'green vehicle financing', where if the vehicle to be financed is a hybrid, electric, or is fuel efficient, the rates applied are lower than other bank's vehicle's credit rates (12\%). CI Banco offers financing services for renewable energy projects for the commercial and residential sectors. Loans finance a maximum of $65 \%$ of the total project cost, and besides a competitive interest rate, apply a $1 \%$ opening commission. CI Banco is strongly interested in offering financial solutions for green projects and is an attractive alternative for partnering and offering a complete project plus financing solution.

Other private banks such as Ixe, Santander, and Banamex also finance solar power installations. They provide financing similar to mortgage loans requesting a mortgage warrantee. Rates fluctuate from $12 \%$ to $16 \%$.

\section{PROPOSALS FOR BCS}

Summarizing the previous sections, BCS is a geographically and electrically isolated state with a relatively small local electricity grid where most power is generated in power plants burning very polluting and expensive fossil fuels that arrive to the state by sea. As a result, the local generation cost is very high and large amounts of tax payers' money are directed to electricity subsidies.

In light of this situation, two proposals have been sketched out to promote the use of GCRPVS in BCS. In the first one, a solar energy service company (SESCO) could install GCRPVS on residential users' roofs. In return, the SESCO would receive the CFE's avoided generation cost of MXN\$3.8259/kWh (some USD 0.29/kWh) and users (roof owners) would get their electricity for free which equates to average savings of MXN\$1.3/kWh (USD 0.1/ $\mathrm{kWh}$ ). Since the SESCO's income depends on keeping the solar system in good operating conditions, the SESCO would also be in charge of maintaining the system. Under this scheme, a SESCO could have access to better financing options and would remove this burden from the individual customer, thus facilitating wide spread access to GCRPVS and reaching environmental and economic benefits and potentially creating a local solar market that at present is almost non-existent in BCS.

A second proposal consists in implementing a FiT for BCS, which is not yet available to residential customers elsewhere in the country. In fact, national policy documents argue 
against the implementation of FiTs, where beneficiaries are paid more than the generation cost [31]. Elsewhere in Mexico, retribution equal to the local cost of generation would not be enough to justify the investment in a GCRPVS, thus discouraging the implementation of such a FiT. However, the high generation costs observed in BCS are sufficient to make such investments worthwhile. The FiT could be funded redirecting the time-of-generation-weighted generation cost (avoided cost, MXN $\$ 3.8259 / \mathrm{kWh}$ ) mentioned above. In addition, the installation of a GCRPVS would also result in net savings derived from avoided electricity purchases to CFE equating to MXN\$1.3/kWh. In total, this would amount to an effective FiT of MXN\$5.1259/kWh (USD 0.39/kWh). Twenty-year cumulative cash flows for both proposals are illustrated in an example GCRPVS of $1 \mathrm{~kW}$ and presented in Fig 4, showing investment recoup times of 8-9 years for the SESCO option and 5-6 for the FiT option (calculations do not include the cost of money).

Alternatively (or in combination), the FiT could also be funded from small increments to electricity prices as is done in other countries. To assess the impact of such a measure, Table 2 presents the amounts that could be potentially raised in BCS for various price increments in the range of MXN\$0.01-0.25 (USD 0.0008-0.0192) per kWh based on the actual 2012 annual

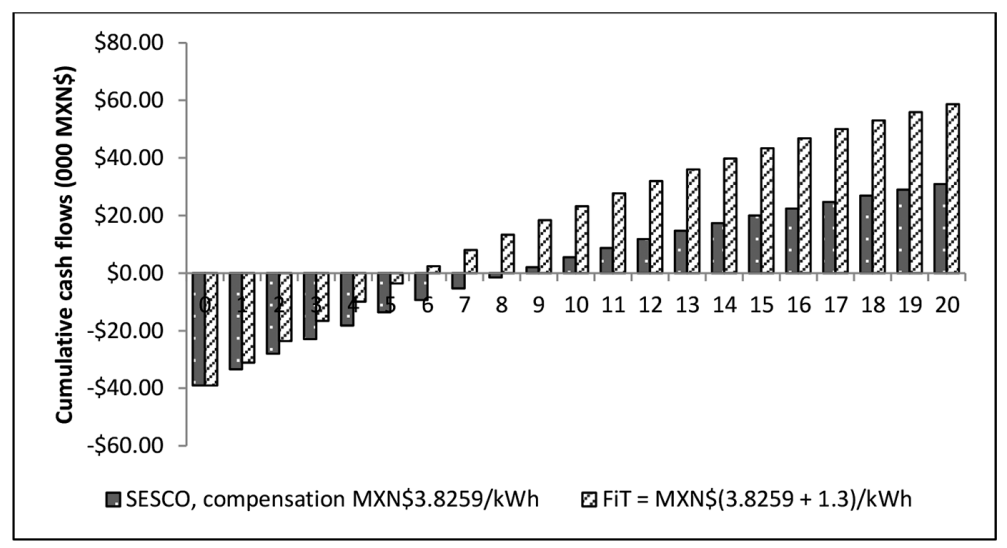

Figure 4: Present value cumulative cash flows for the two proposals for a $1 \mathrm{~kW}$ GCRPVS, including yearly maintenance costs. Inflation $=4 \%$, discount rate $=10 \%$.

Table 2: Fund-raising example for a FiT in BCS for various price increments.

\begin{tabular}{lccc}
\hline & \multicolumn{3}{c}{ FiT $=\$ 3.8259 / \mathrm{kWh}$} \\
\hline $\begin{array}{l}\text { Price } \\
\text { increase per } \\
\mathrm{kWh}\end{array}$ & $\begin{array}{l}\text { Raised amount } \\
(\mathrm{MXN} \$)\end{array}$ & $\begin{array}{l}\text { Total electricity that the } \\
\text { raised amount (FiT) could } \\
\text { pay for }(\mathrm{kWh})\end{array}$ & $\begin{array}{l}\text { Corresponding approximate } \\
\text { PV capacity }(\mathrm{kW})\end{array}$ \\
\hline$\$ 0.01$ & $\$ 20,239,378$ & $5,290,096$ & 2899 \\
$\$ 0.05$ & $\$ 101,196,888$ & $26,450,479$ & 14,493 \\
$\$ 0.10$ & $\$ 202,393,775$ & $52,900,958$ & 28,987 \\
$\$ 0.25$ & $\$ 505,984,438$ & $132,252,395$ & 72,467 \\
\hline
\end{tabular}


sales of $2024 \mathrm{GWh}$. The table also shows the amount of kWh that the raised funds could cover if paid a FiT equal to the avoided cost and the solar PV capacity required to generate those $\mathrm{kWh}$. While this exercise gives good indication of what could be achieved, very well designed strategies for implementation must be in place (and fall outside the scope of this work).

\section{CONCLUSIONS}

Electricity generation in BCS is achieved almost entirely by burning heavy fuel oil and diesel fuel transported to the state from elsewhere in Mexico and abroad, resulting in a very high emissions factor for electricity consumption of $0.892 \mathrm{~kg} \mathrm{CO}_{2}$ e per $\mathrm{kWh}$ and also in local generation costs amongst the highest in Mexico. On the other hand, solar energy is abundant in BCS and is already exploited for electricity generation in grid-connected systems although numbers are still very low to have a significant impact on generation levels, emissions or the local economy, despite the existence of several financing mechanisms available in Mexico. The availability of suitable innovative promotion and financing mechanisms in BCS could help in achieving an extensive roll out of GCRPVS technology with the corresponding benefits.

In order to sketch out proposals to achieve a greater uptake of GCRPVS in BCS, annual electricity subsidies for residential electricity were estimated at MXN\$1532 million (Table 1), the avoided unit electricity cost derived from the time of use of GCRPVS was valued at MXN $\$ 3.8259 / \mathrm{kWh}$ and the average price of electricity at MXN\$1.3/kWh. Based on these figures, two proposals were presented. In the first one, a SESCO would source, install, and maintain GCRPVS on consumers' roofs in return for the avoided generation cost as compensation. The user would use the generated electricity free of charge and stop paying the current provider CFE (savings equivalent to MXN\$1.3/kWh). This approach removes the financing burden from the residential user and passes it on to the SESCO who would be in a position to access better financing deals.

The second proposal involves the implementation of a FiT that could be funded adding up the avoided cost and the users' electricity savings for a total amount of MXN\$5.1259/kWh. Alternatively, the FiT could also be funded by small increases in electricity prices to all consumers, which was also explored.

BCS has a number of characteristics that place it as an ideal location to implement and trial innovative financing and promotion schemes for GCRPVS that could make their widespread use possible. With careful implementation, these schemes not yet applied in Mexico could help reduce emissions from conventional generation, create a local renewable industry and market, and even reduce residential customers' electricity bills.

\begin{tabular}{ll} 
& \multicolumn{1}{c}{ LIST OF ACRONYMS } \\
CFE & Federal Electricity Commission \\
FiT & Feed-in Tariff \\
GCRPVS & Grid-Connected Residential Photovoltaic Systems \\
GHGE & Greenhouse Gas Emissions \\
IEA & International Energy Agency \\
IPP & Independent Power Providers \\
IRENA & International Renewable Energy Agency \\
LAERFTE & Renewable Energies Exploitation and Energy Transition Financing Law \\
LSPEE & Electric Energy Public Service Law \\
RE & Renewable Energy \\
STTC & Short Term Total Cost
\end{tabular}




\section{REFERENCES}

[1] INEGI, Principales resultados del Censo de Población y Vivienda 2010, 2011, Available at http://www.inegi.org.mx/sistemas/biblioteca/detalle.aspx?c=28097\&upc=7028250 $02042 \& \mathrm{~s}=\mathrm{est} \& \operatorname{tg}=320 \& \mathrm{f}=2 \& \mathrm{pf}=\mathrm{Pob} \& \mathrm{ef}=00 \& \mathrm{cl}=0$. Tasa de crecimiento poblacional nacional (accessed 2 July 2012).

[2] CFE, Programa de Obras e Inversiones del Sector Eléctrico 2012-2026, Available at http://www.cfe.gob.mx/ConoceCFE/1_AcercadeCFE/Paginas/Publicaciones.aspx (accessed: 22. April 2013).

[3] CFE, Programa de Obras e Inversiones del Sector Eléctrico 2011-2025,available at http://www.energia.gob.mx/portal/Mobil.aspx?id=1453 (accessed: 19. February 2012).

[4] IPCC, Climate Change 2007: Mitigation. Contribution of Working Group III to the Fourth Assessment Report of the Intergovernmental Panel on Climate Change, Cambridge University Press: Cambridge, UK and New York, NY, USA, 2007, ISBN 978-0-521-70598-1.

[5] IEA, Key World Energy Statistics, 2012, Available at http://www.iea.org (accessed 21 September 2012).

[6] IPCC, IPCC Special Report on Renewable Energy Sources and Climate Change Mitigation, Cambridge University Press: Cambridge, UK and New York, NY, USA, 2011.

[7] Bermudez-Contreras, A., Ivanova Boncheva, A. \& Martinez De La Torre, A. A methodology to estimate the potential of grid-connected PV residential systems for greenhouse gas emission reductions, The Sustainable City IX, In: eds. N. Marchettini, NC.A., Brebbia, C.A.R., Pulselli, R. and \& S. Bastianoni, S., eds.WIT Press, 2014, (accessed: 26. October 2014). doi: 10.2495/SC140922

[8] Bermudez-Contreras, A., Thomson, M. \& Infield, D.G., Renewable energy powered desalination in Baja California Sur, Mexico. Desalination, 220(1-3), pp. 431-440, 2008. ISSN 00119164: doi: 10.1016/j.desal.2007.01.046

[9] Bermudez Contreras, A.S., Energías renovables para la generación de electricidad en Baja California Sur, Baja California Sur ante el cambio climático: Vulnerabilidad, adaptación y mitigación, In:eds. A. Ivanova, A., and A.E. Gámez, A.E., eds., UABCS: La Paz, pp. 384-415, 2013. ISBN 978-607-7777-32-8.

[10] Ghosh, D., Shukla, P.R., Garg, A. \& Ramana, P.V., Renewable energy technologies for the Indian power sector: mitigation potential and operational strategies. Renewable and Sustainable Energy Reviews, 6(6), pp. 481-512, 2002. ISSN 1364-0321: doi: http:// dx.doi.org/10.1016/S1364-0321(02)00015-1

[11] Sims, R.E.H., Rogner, H.-H. \& Gregory, K., Carbon emission and mitigation cost comparisons between fossil fuel, nuclear and renewable energy resources for electricity generation. Energy Policy, 31(13), pp. 1315-1326, 2003. ISSN 0301-4215: doi: http:// dx.doi.org/10.1016/S0301-4215(02)00192-1

[12] Winkler, H., Hughes, A. \& Haw, M., Technology learning for renewable energy: implications for South Africa's long-term mitigation scenarios. Energy Policy, 37(11), pp. 4987-4996, 2009. ISSN 0301-4215: doi: http://dx.doi.org/10.1016/j. enpol.2009.06.062

[13] Mathiesen, B.V., Lund, H. \& Karlsson, K., 100\% Renewable energy systems, climate mitigation and economic growth. Applied Energy, 88(2), pp. 488-501, 2011, ISSN 0306-2619: doi: http://dx.doi.org/10.1016/j.apenergy.2010.03.001 
[14] McHenry, M.P., A technical, economic, and greenhouse gas emission analysis of a homestead-scale grid-connected and stand-alone photovoltaic and diesel systems, against electricity network extension. Renewable Energy, 38(1), pp. 126-135, 2012. ISSN 09601481: doi: 10.1016/j.renene.2011.07.020

[15] Mahesh, A. \& Shoba Jasmin, K.S., Role of renewable energy investment in India: an alternative to $\mathrm{CO}_{2}$ mitigation. Renewable and Sustainable Energy Reviews, 26, pp. 414 424, 2013 (accessed 10 October 2013). ISSN 13640321: doi: 10.1016/j.rser.2013.05.069

[16] Narbel, P.A., What is really behind the adoption of new renewable electricity generating technologies? Energy for Sustainable Development, 17(4), pp. 386-390, 2013. ISSN 0973-0826. doi: http://dx.doi.org/10.1016/j.esd.2013.03.002

[17] Schmid, E., Pahle, M. \& Knopf, B., Renewable electricity generation in Germany: a meta-analysis of mitigation scenarios. Energy Policy, 61, pp. 1151-1163, 2013. ISSN 0301-4215: doi: http://dx.doi.org/10.1016/j.enpol.2013.06.105

[18] REN21., Renewables 2013 Global Status Report, REN21 Secretariat: Paris, 2013. ISBN 9783981593402: http://www.ren21.net/REN21Activities/GlobalStatusReport.aspx

[19] Šúri, M., Huld, T.A., Dunlop, E.D. \& Ossenbrink, H.A., Potential of solar electricity generation in the European Union member states and candidate countries. Solar Energy, 2007, 81, pp. 1295-1305, Available at http://re.jrc.ec.europa.eu/pvgis (accessed 27. July 2011).

[20] CFE, Despacho y Control de Energía, 2014, Available at http://app.cfe.gob.mx/Aplicaciones/OTROS/costostotales/ConsultaArchivoBalance.aspx (accessed 5 April 2014).

[21] IEA and IRENA, IEA/IRENA Joint Policies Database, 2013, available at http://www. iea.org/policiesandmeasures/renewableenergy/ (accessed 1 August 2014).

[22] REN21, Renewables 2014 Global Status Report, REN21 Secretariat: Paris, 2014, Available at http://www.ren21.net/Portals/0/documents/Resources/GSR/2014/GSR2014_ full report_low res.pdf ([accessed: 11. August 2014].). ISBN 9783981593426.

[23] Jacobs, D. \& Sovacool, B.K., Feed-in tariffs and other support mechanisms for solar PV promotion, Comprehensive Renewable Energy, Sayigh, A., ed., Elsevier, 2012, pp. 73-109. ISBN 9780080878737: doi: 10.1016/B978-0-08-087872-0.00104-9

[24] Moner-Girona, M., Szabo, S. \& Rolland, S., Finance mechanisms and incentives for photovoltaic technologies in developing countries, Comprehensive Renewable Energy, Sayigh, A., ed., 2012. ISBN 9780080878720: doi: 10.1016/B978-0-08-087872-0.00148-7

[25] Porter, D., Renewable energy policy and incentives, Comprehensive Renewable Energy, In: Sayigh, A., ed. 2012, pp. 1-4. ISBN 9780080878720: doi: 10.1016/B978-0-08087872-0.00901-X

[26] LSPEE, Ley del Servicio Público de Energía Eléctrica, Electric Energy Public Service Law, Presidencia de la República, 1975, available at http://www.diputados.gob.mx/ LeyesBiblio/pdf/99.pdf

[27] LASE, Ley para el Aprovechamiento Sustentable de la Energía, Sustainable Energy Usage Law, Presidencia de la República, 2008, available at http://www.diputados.gob. $\mathrm{mx} /$ LeyesBiblio/pdf/LASE.pdf

[28] CFE, Comportamiento de los contratos de interconexión en pequeña y mediana escala, "Low and Medium Scale Interconnection Contracts' Performance”, CFE, 2013, Available at http://www.cre.gob.mx/documento/2109.pdf (accessed 11 March 2013).

[29] ProMéxico, Energías Renovables, Renewable Energies, Unidad de Inteligencia de Negocios: México, 2013. 
[30] LAERFTE, Ley para elAprovechamiento de las Energías Renovables yel Financiamiento de la Transición Energética, Renewable Energies Exploitation and Energy Transition Financing Law, Presidencia de la República, 2008, available at http://www.cre.gob.mx/ documento/1523.pdf

[31] SENER, Prospectiva de Energías Renovables 2013-2027, 2013, available at http:// sener.gob.mx/res/PE_y_DT/pub/2013/Prospectiva_del_Sector_Electrico_2013-2027. pdf (accessed 2 April 2014). 